\title{
Konsep Deradikalisasi Pada Pendidikan Berbasis Pembelajaran Terpadu
}

\author{
Putri Hergianasari \\ hergianasari.putri@staff.uksw.edu \\ Hubungan Internasional FISKOM Universitas Kristen Satya Wacana
}

The Concept Of Deradicalization In Education Based On Integrated Learning

\begin{abstract}
Young people are one of the targets of terrorism groups in recruiting new members. Some terrorists who have been arrested show their status as students or young people. This study discusses the concept of deradicalization in integrated learning-based education, namely on subjects of citizenship, history, religion, also counseling and guidance. In addition, one important way to be developed in the environment of the younger generation is to conduct campaigns against radicalism and peace on a regular basis. This is the right way to improveor recover the situation from radical acts and terrorism. This study uses a literature study method with a qualitative descriptive approach. The unit of analysis of this research is the younger generation who are vulnerable to radicalism. The conclusion is that integrated learning education can strengthen the values of the national character of the younger generation to prevent and fight radicalism.
\end{abstract}

Keywords: Radicalism, Terrorism, Peacebuilding, Integrated Learning

Article Info

Received date: 10 Agustus 2019 Revised date: 20 Agustus $2019 \quad$ Accepted date: 19 September 2019

\section{PENDAHULUAN}

Akhir tahun 2018 aksi berbagai kelompok keagamaan terlihat kuat, dan gesekan-gesekan antar pemeluk agama di era global semakin besar ketika demokratisasi diluaskan, akhirnya semakin mudah melahirkan konflik dan muncul paham-paham radikal. Indonesia merupakan salah satu negara yang besar dan penuh dengan keberagaman, merupakan salah satu negara dengan jumlah penduduk terbanyak di dunia, kekayaan yang melimpah, keberagaman etnis, suku, budaya dan agama. Dengan semua keberagaman tersebut, Indonesia telah memiliki pengalaman yang sangat banyak dan menarik yang dapat menjadi pembelajaran berharga bagi masa depan bangsa, sekaligus dapat menjadi model bagi bangsa lain tentang bagaimana mengelola keberagaman etnis, budaya dan agama dalam kehidupan modern yang kompleks.

Akan tetapi keberagaman tersebut apabila tidak dijaga dan dilestarikan dengan tepat, akan menimbulkan konflik yang lebih besar lagi. Apalagi aksi-aksi terror yang terjadi pada akhir tahun 2018 yang terjadi di gereja di Surabaya menimbulkan pertanyaan yang besar, Kemanakah kebhinekaan Indonesia yang dulu terjalin dengan damai? Hal tersebut terjadi karena munculnya paham radikalisme.

Paham radikal lebih menyasar pada generasi muda. Urgensi permasalahan yang muncul dalam generasi muda yaitu generasi muda merupakan masa transisi dan krisis akan identitas, yang disebut dengan cognitive opening yaitu proses secara mikro sosiologis, proses ini mendekatkan generasi muda untuk dapat dengan mudah menerima gagasan baru. Alasan psikologis itulah yang menyebabkan generasi muda rentan terhadap pengaruh ideologi radikal. selain itu, kurangnya pengetahuan tentang bahaya radikalisme, jika sebelumnya proses rekrutmen anggota paham radikal berjalan secara sembunyi-sembunyi dengan sistem sel, rekrutmen anggota baru menjadi lebih terbuka. Menyasar generasi muda yang memiliki ghirah keagamaan tinggi tetapi memiliki bekal pengetahuan agama minim, paham radikalisme dan terorisme disalurkan lewat beberapa kegiatan yang bersifat militansi, ekstremisme, dan eksklusifisme, tahun politik (2019) sangat berpengaruh pada perluasan pemahaman radialisme, bahkan pemahaman berbahaya tersebut sebagian besar ditunggangi oleh aktivitas dan kepentingan parpol dan yang terakhir konten yang bermuatan radikal dalam internet dan media sosial menyasar para generasi muda. 
Pemberantasan tindak pidana terorisme tertuang dalam Undang-Undang Republik Indonesia No. 5 tahun 2018. Terorisme menyatakan bahwa pencegahan yang terdapat dalam UU Terorisme hanya menindak dengan menggunakan pendekatan yang keras sehingga UU Terorisme mempunyai celah kelemahan terkait meredam dan menghambat laju penyebaran paham radikal di lembaga pendidikan. Untuk mengantisipasi paham radikal harus dilakukan sedini mungkin, terutama dilembaga pendidikan, apabila sudah terindikasi paham radikal, pemerintah terutama Badan Nasional Penanggulangan Terorisme (BNPT) dan lembaga-lembaga pendidikan harus mempunyai program untuk deradikalisasi. Berdasarkan permasalahan tersebut rumusan masalah dalam kajian ini adalah bagaimana konsep deradikalisasi pada pendidikan berbasis pembelajaran terpadu.

Tujuan dari kajian ini yaitu generasi muda memperoleh pengetahuan tentang bahaya radikalisme melalui muatan dalam mata pelajaran yang sesuai. Proses memasukkan materi atau pemahaman tentang deradikalisasi secara praktik menggunakan proses tematik terpadu secara kontekstual yang digunakan untuk meningkatkan kebermaknaan (Mawardi, Wardani, Hardini, \& Kristin, 2019), bahwa tindakan radikal yang mengacu kepada tindakan terorisme dalam skala apapun melanggar ketentuan undang-undang dan bertentangan dengan asas ideologi Pancasila. Sistem pembelajaran ini mengedukasi generasi muda tentang kerentanan kaum muda dalam menerima segala informasi, mengedukasi generasi muda bahwa paham radikalisme dan terorisme disalurkan lewat beberapa kegiatan yang bersifat militansi, ekstremisme, dan eksklusifisme, mengedukasi tenaga pengajar untuk menanamkan nilai-nilai nasionalisme, mengedukasi generasi muda bahwa tahun politik (2019) sangat berpengaruh pada perluasan pemahaman radialisme, bahkan pemahaman berbahaya tersebut sebagian besar ditunggangi oleh aktivitas dan kepentingan partai politik.

\section{KAJIAN PUSTAKA}

Perkembangan jaringan terorisme di Indonesia mengalami kemajuan yang pesat dari tahun ke tahun. Pada masa perkembanganya, mempunyai faktor penyebab radikalisasi yang berbeda-beda, akan tetapi dari tahun ke tahun saling keterkaitan satu dengan yang lainnya. Paham radikal merupakan aspek yang penting untuk menganalisis perkembangan terorisme yang ada di Indonesia. Pada hakekatnya tidak seorangpun yang dilahirkan menjadi teroris, sehingga apabila seseorang terlibat dalam kelompok teroris dapat dikategorikan sebagai proses radikalisasi, oleh karena itu pelaku teror dapat direhabilitasi agar dapat terlepas dari paham radikal yang menjurus kepada tindakan terorisme (Zachary,2009).

Terdapat enam area yang dapat diidentifikasikan sebagai akar penyebab terorisme, yaitu negara yang lemah, kemiskinan, konflik yang disusupi oleh kelompok ekstrimis agama tertentu, adanya pendanaan dari pihak luar, demokrasi yang lemah, rekrutmen dan mobilisasi transnasional (Karvin,2011-2012: 103). Selain itu terorisme berakar pada kondisi tertentu yang disebut sebagai the mother of all terrorism yaitu konflik Israel-Palestina, dukungan negara terhadap terorisme (Bjorgo,2005).

Permasalahan yang terdapat dalam pendidikan di Indonesia yaitu yang pertama adalah kuantitas, kuantitas merupakan kondisi penyebaran yang tidak merata terhadap lembaga pendidikan dan tenaga pengajar yang ada di wilayah Indonesia. Contohnya yaitu ketimpangan tenaga pengajar dan jumlah sekolah-sekolah di desa dan di kota sangat signifikan. Permasalahan yang kedua adalah kualitas pendidikan yang rendah, metode pengajaran hanya berorientasi meningkatkan intelektualitas semata sehingga filosofi pendidikan terkait nilai-nilai luhur bangsa dan pendidikan spiritual dikesampingkan. Sejatinya pendidikan merupakan proses untuk meningkatkan intelektualitas dan spiritualitas. Oleh karena itu peningkatan kuantitas pendidikan harus selaras dengan peningkataan kualitas pendidikan pada lembaga formal yang ada di Indonesia.

Data Kementrian Pembangunan Daerah Tertinggal (PDT) tahun 2018 menyatakan bahwa ratarata angka melek huruf masyarakat daerah tertinggal adalah $26 \%$ dari jumlah total masyarakat (PDT, 2018). Hal tersebut merupakan angka yang rendah karena rata-rata nasional angka melek huruf adalah 91\%, hal ini berarti ketimpangan memang terjadi pada penyebaran pendidikan yaitu kuantitas pendidikan. Sehingga kondisi ketimpangan menyebabkan timbulnya masyarakat yang termarjinalisasikan dan kurangnya kepercayaan kepada pemerintah karena pendidikan yang tidak merata tersebut. Sehingga dengan kondisi tersebut dapat dengan mudah disusupi paham radikal dengan iming-iming guna memenuhi kebutuhan hidup. 
Pembelajaran terpadu yang dapat digunakan sebagai konsep deradikalisasi menurut Robin Forgarty dalam Buku How to Integrate The Curricula (Fogarty \& Pete, 2009) mempunyai sepuluh model yaitu, a. model penggalan (fragmented) yaitu pemaduan yang terbatas pada satu pelajaran saja, b. model keterhubungan yaitu pembelajaran dapat dipayungkan pada induk mata pelajaran tertentu, c. metode sarang (nested), yaitu paduan berbagai bentuk penguasaan konsep dan ketrampilan melalui kegiatan pembelajaran. d. model urutan (sequenced), yaitu model paduan topik-topik antar mata pelajaran yang berbeda secara parrel. e. model bagian (shared), yaitu pembelajaran akibat adanya overlapping dua pelajaran atau lebih. f. model jaring laba-laba (webbed), yaitu tema dapat mengkaitkan kegiatan pembelajaran baik dalam mata pelajaran tertentu maupun lintas pelajaran. g. model galur (threaded), yaitu paduan bentuk ketrampilan dengan cara melakukan prediksi atau estimai. h. model keterpaduan (integrated), yaitu paduan sejumlah topik dari pelajaran yang berbeda akan tetapi mempunyai esensi yang sama dalam topik tertentu. i. model celupan (immersed), yaitu membantu siswa dalam menyaring dan memadukan berbagai pengalaman dan pengetahuan. j. model jaringan (network), yaitu model paduan pembelajaran untuk pengubahan konsep, pemecahan masalah. Pada kajian ini penulis menggunakan model pembelajaran keterpaduan (integrated) dengan memadukan sejumlah mata pelajaran yang berbeda, tetapi mempunyai esensi yang sama akan sebuah topik tertentu yaitu deradikalisasi.

Pembelajaran terpadu disini merupakan suatu pendekatan untuk pembelajaran yang dengan sengaja mengkaitkan beberapa aspek dalam intra pelajaran mupun antar pelajaran. Dengan adanya pemaduan tersebut, diharapkan akan mendapatkan pengetahuan dan ketrampilan secara holistik sehingga pembelajaran menjadi bermakna untuk siswa. Siswa akan dengan mudah memahami konsepkonsep yang dipelajari melalui pengalaman langsung yang menghubungkan antar konsep dan intra pelajaran maupun antar pelajaran.

Penelitian tentang pembelajaran terpadu juga ditulis oleh Uum Murfiah dosen PGSD FKIP Universitas Pasundan Bandung dengan judul Model Pembelajaran Terpadu di Sekolah Dasar dengan menggunakan model pembelajaran terintegrasi menggunakan pendekatan subyek, yaitu pendekatan yang mengintegrasikan antar topik dengan menggabungkan konsep dalam pelajaran matematika, sains, bahasa dan seni serta sosial. Model ini diimplementasikan dengan menggbungkan mata pelajaran interdisipliner, serta menetapkan prioritas materi pelajaran, ketrampilan, konsep, serta sikap yang terkait dalam mata pelajaran. (Murfiah, 2017)

Artikel dengan judul Curriculum Integration: An Overview oleh Amanda Wall dari Georgia Southern University menyatakan bahwa integrasi kurikulum cocok digunakan pada tingkat pendidikan menengah (SLTP) karena dapat digunakan sebagai pendukung dalam menyusun kurikulum sehingga lebih eksploratif, relevan, integratif dan bermakna bagi siswa remaja. Pengajar dapat mengintegrasikan kurikulum diseluruh bidang dengan konten yang telah disepakati bersama dengan siswa dengan tidak mengurangi substansi dari mata pelajaran yang utama. (Wall, 2017).

Penelitian dengan judul Pengembangan Model Pembelajaran Praktik Terpadu Siswa SMK Pariwisata oleh Kristiyanto dari Universitas Negeri Yogyakarta, menggunakan pembelajaran terpadu dengan menggabungkan materi kejuruan kelas X semester 2 dan kelas XI semester 1 dengan mata pelajaran Akomodasi Perhotelan dan Usaha Perjalanan Wisata yang diajarkan secara terus-menerus dan berkelanjutan. Tujuan penelitian ini adalah lulusan SMK Pariwista mempunyai kompetisi yang dibutuhkan oleh perusahaan. (Kristiyanto, 2015).

Penelitian terkait deradikalisasi dalam mata pelajaran di sekolah juga ditulis oleh Mahfud Junaedi dalam artikel yang berjudul Pengembangan PAI Kontra Radikalisme. Tulisan ini membahas radikalisme dengan memasukkan kedalam kurikulum pendidikan agama Islam dengan mengkaitkan nilai-nilai kontra radikalisme yaitu pada ranah kognitif, afekti dan psikomotorik. Materi disajikan secara eksplisit dan juga disampaikan sebagai sisipan ketika proses pembelajaran. (Junaedi, 2018).

Sedangkan kebaharuan dari penelitian ini adalah dengan mengintegrasikan mata pelajaran PPKn, Agama,Sejarah, serta Bimbingan Konseling untuk memasukkan konsep deradikalisasi kedalam kurikulum pembelajaran baik secara eksplisit maupun implisit.

\section{METODE PENELITIAN}

Penelitian ini menggunakan metode studi literatur dengan pendekatan penelitian kualitatif deskriptif. Dalam arti data yang dikumpulkan bukan merupakan data angka, akan tetapi berasal dari 
dokumen resmi, buku, jurnal dan situs resmi. Sehingga yang menjadi tujuan penelitian deskriptif kualitatif ini yaitu berusaha menggambarkan realita empirik dibalik suatu fenomena yang dilakukan dengan analisis secara mendalam. Penggunaan pendekatan kualitatif deskriptif pada penelitian ini dengan cara mengkonfirmasi antara realita empirik dengan teori yang digunakan secara deskriptif. Jenis penelitian dalam kajian ini adalah menggunakan telaah kepustakaan dengan menggunakan metode dokumentasi untuk pengumpulan data. Data yang telah terkumpul kemudian di pilah-pilah dan direduksi sesuai dengan kebutuhan dari penelitian. Data yang dipilah kemudian dianalisi dan diinterpretasikan sesuai dengan teori.

Sumber data pada penelitian ini mengunakan buku terorisme yaitu The Rehabilitation of Jemaan Islamiyah Derainees in South East Asia: A Preliminary Assessment Zachary Abuza, buku pembelajaran terpadu karya Robin Forary dengan judul How to Integrate The Curriculla, jurnal terorisme serta situs resmi Badan Nasional Penanggulangan Terorisme (BNPT) www.bnpt.go.id. Teknik pengumpulan data berjenis studi pustaka menggunakan metode dokumentasi. Penulis mengidentifikasi wacana yang diperoleh dari sumber data yang kemudian mencari data terkait rumusan masalah yang diteliti. Tahapan pengumpulan data yaitu yang pertama mengumpulkan bahan pustaka yang dijadikan sebagai sumber data, kedua memilih bahan pustaka yang dijadikan sumber data utama, ketiga, membaca bahan pustaka dan menganalisis, keempat membuat catatan dan mengklasifikasi yang merujuk pada rumusan masalah penelitian.

Teknik analisis data menggunakan analisis isi (content analysis) untuk mengumpulkan dan menganalisis dokumen sesuai dengan masalah yang dibahas (Klaus Krippendorf, 2004) serta historis yaitu melakukan analisis tekait penemuan apa saja yang terjadi pada masa lalu. Kemudian analisis historis memerlukan analisis kritis (critical analysis) yang digunakan untuk mengungkapkan fakta terhadap suatu fenomena sehingga dapat membuat konsep dari analisis yang kritis.

\section{HASIL PENELITIAN DAN PEMBAHASAN}

Penelitian ini memilih Integrated Model pada model pembelajaran terpadu karena dianggap sesuai dengan menjawab konsep dari rumusan masalah. Integrated Model dengan penggabungan mata pelajaran dengan menemukan inovasi atau kreativitas di dalamnya. Menggabungkan konsep dan metode pembelajaran yang mempunyai ketertaikat di dalam empat mata pelajaran, dengan menggunakan pendekatan antar mata pelajaran. Integrated Model menggabungkan mata pelajaran dengan memprioritaskan latar belakang kurikulum pada tiap-tiap penemuan konsep dan ketrmpilan.

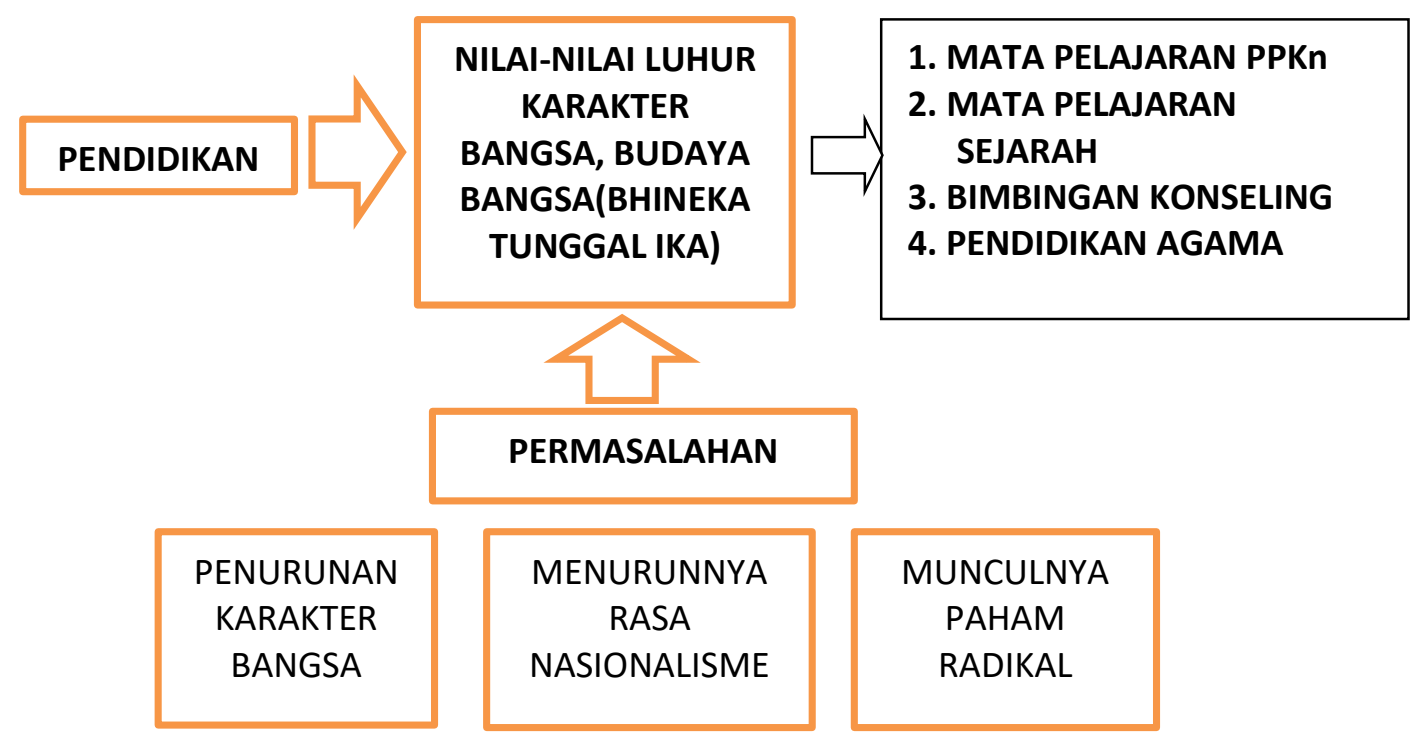

\section{Bagan 1. Konsep Deradikalisasi Paham Radikal Berbasis Pembelajaran Terpadu}

Dari bagan di atas menjelaskan bahwa terdapat strategi dalam deradikalisasi paham radikal, pertama dengan cara pendidikan nilai-nilai luhur karakter bangsa Indonesia. Melalui mata pelajaran atau mata kuliah PPKn bagi siswa-siswi dan bahkan bagi mahasiswa. Landasaan idiil bangsa Indonesia 
yaitu Pancasila ditanamkan dalam bangku sekolah. Mata pelajaran Sejarah juga dapat ditanamkan nilainilai luhur sejarah perjuangan pahlawan yang merebut Indonesia dari tangan penjajah, dengan beraneka suku, ras dan agama bersatu untuk memerdekakan Indonesia. Pada mata pelajaran Agama, nilai-nilai deradikalisasi ditanamkan dengan cara mengajarkan jalan kebenaran tanpa menjelek-jelekan agama lain. Agama yang diajarkan harus sesuai dengan nilai-nilai Pancasila. Agama harus dapat mendudukan sebagai pilar kebangsaan, dengan maksud ajaran agama membuat manusia dapat bertoleransi dan mendukung satu sama lain dalam kehidupan berbangsa dan bernegara. Mata pelajaran Bimbingan Konseling, juga dapat ditanamkan nilai-nilai preventif radikalisasi dengan menyasar psikologis generasi muda yang rentan disusupi oleh paham radikal. Deradikalisasi dalam Bimbingan Konseling dengan cara pendampingan secara psikologis.

Strategi deradikalisasi yang kedua adalah dengan pembinaan komunitas melalui karangtruna, sekolah dan komunitas-komunitas muda lainnya dengan bentuk sosialisasi serta mengkampanyekan peace building. Tidak hanya itu, paham radikal juga dapat muncul melalui pengajaran yang salah atau menyimpang, oleh karena itu pengajar, guru, dosen juga harus mendapatkan pembinaan deradikalisasi paham radikal serta pelatihan terkait preventif paham radikal. Strategi yang ketiga yaitu dengan pembudayaan, yang dimaksud disini adalah membiasakan bersikap toleransi, tenggang rasa dan menghargai sesama, dapat bergotong royong sehingga tidak menjadi egois dan individual.

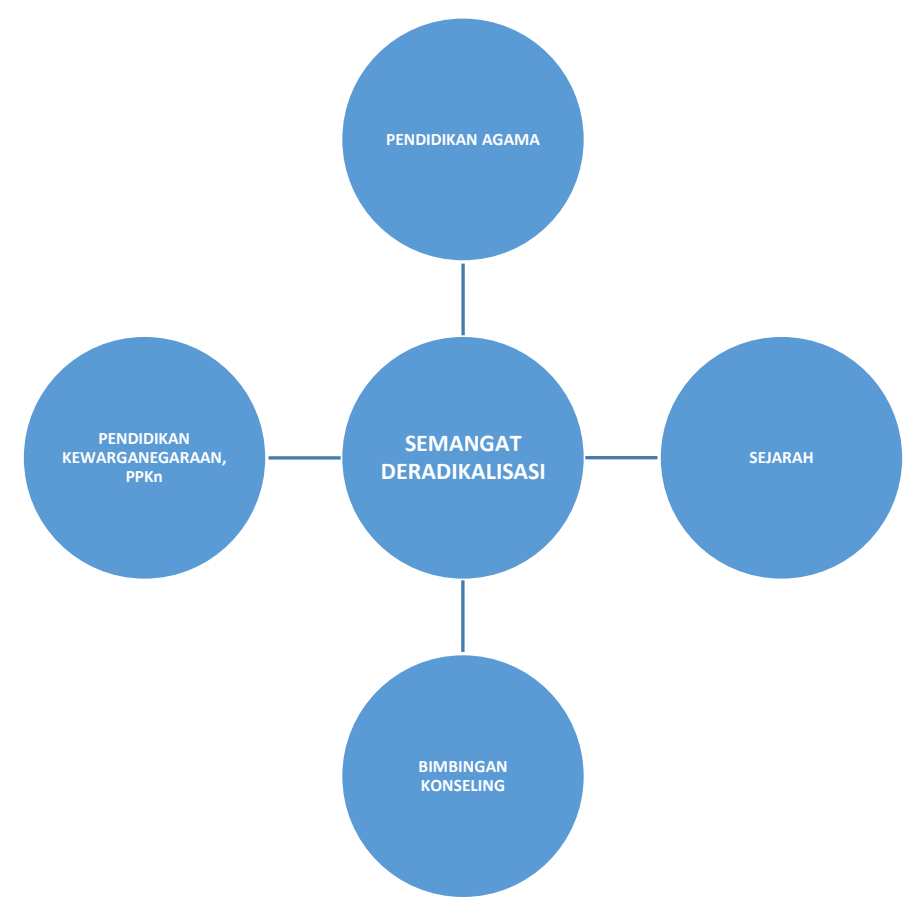

Gambar 1. Intergasi Mata Pelajaran Deradikalisasi

Penelitian ini membuat konsep mata pelajaran Sejarah, PPKn, Bimbingan Konseling, Agama menjadi model perpaduan/ integrasi dengan cara pengajar menentukan konsep dan ketrampilan yang akan diajarkan pada satu semester. Dengan mengkonsepkan sebagai berikut: 1. Konsep dari mata pelajaran Sejarah: a. konsep sejarah perjuangan bangsa melawan penjajah untuk merebut kemerdekaan, membuktikan bahwa kedamaian adalah sesuatu yang diperjuangkan dengan harga yang mahal. Fakta sejarah ini digunakan sebagai rambu-rambu ideologi bahwa radikalisme memiliki dampak perusakan yang sangat dahsyat dan efek yang timbulkan tidak mudah sirna dan membuat penderitaan bagi rakyat. b. berjuangan bersama-sama dengan suku, ras, agama yang berbeda. c. Sejarah ketika Soekarno menolak Piagam Jakarta yang merupakan cikal-bakal lahirnya Undang-Undang Dasar 1945 dengan butir yang pertama yaitu " ketuhanan dengan kewajiban menjalankan syari'at Islam bagi pemelukpemeluknya. (Hergianasari, 2018)

Kedua, konsep dari mata pelajaran PPKn: a. konsep tenggang rasa, b. ketertiban, c. toleransi, d. falsafah Pancasila, e. konstitusional Indonesia yaitu UUD 1945. Ketiga, konsep dari mata pelajaran Agama: a. bagaimana agama dapat mengatur dimensi jiwa atau rohani seseorang untuk hidup damai sebagai kerangka inti pemahaman kedamaian dari agama yaitu sebagai tuntunan hidup manusia yang 
paling dasar. b. Konsep pemahaman agama hendaknya sesuai dengan tujuan bahwa agama sebagai pilar kebangsaan yang damai dan bertoleransi. c. pengajar pendidikan agama harus terkoordinasi dengan baik sehingga muatan-muatan pelajaran yang diajarkan tidak mengandung unsur paham radikal

Keempat, Konsep mata pelajaran Bimbingan Konseling: a. Menyentuh psikologis siswa secara mendalam, b. Sebagai media untuk melihat karakteristik dasar manusia dalam berinteraksi dengan lingkungan, c. Sebagai bentuk pelatihan untuk peningkatan secara praaktis dan aktif untuk memahami kebutuhan hidup bertoleransi kebangsaan yang majemuk sesuai dengan pilar universal/ interaksi kemanusiaan yang adil dan beradab. d. Motor kampanye gerakan anti teroris.

\section{SIMPULAN DAN SARAN}

Konsep deradikalisasi berbasis pembelajaran terpadu melalui mata pelajaran Sejarah, PPKn, Agama dan Bimbingan Konseling adalah untuk membentuk national culture dan peacebuilding. Sehingga dapat menciptakan harmoniasi dalam keberagaman yang sesuai dengan falsafah Indonesia yaitu Pancasila tujuan memuat konsep anti terorisme dan deradikalisasi pada mata pelajaran Sejarah, Pendidikan Agama, PPKn serta Bimbingan Konseling untuk penanaman nilai-nilai deradikalisasi sehingga membentuk lingkungan yang dapat mempengaruhi kelompok sosial siswa, tidak hanya lingkungan sekolah dan keluarga.

Saran untuk penelitian selanjutnya, penelitian ini merupakan tataran konsep, perlu mendapatkan kajian lebih lanjut tentang aplikasi dari pembelajaran terpadu dengan menggunakan radikalisme sebagai tema.

\section{DAFTAR PUSTAKA}

Abuza, Zachary. 2009. The Rehabilitation of Jemaan Islamiyah Derainees in South East Asia: A Preliminary Assessment dalam Tore Bjorgo dan John Horgan Leaving Terrorism Behind, Routledge. 196.

Fogarty, R., \& Pete, B. M. 2009. How to integrate the curricula (3rd ed). Thousand Oaks, Calif: Corwin.

Hergianasari, P. 2018. Pembentukan Deradikalisasi Paham Islam Radikal Terhadap Bangkitnya Terorisme Di Indonesia Berdasarkan Perspektif Konstruktivisme. Cakrawala, 7(1), 45-64.

Junaedi, M. 2018. Pengembangan PAI kontra radikalisme. Conference presented at the Forum Diskusi Ilmiah Dosen Fakultas Ilmu Tarbiyah dan Keguruan UIN Walisongo Semarang, Semarang. Retrieved from http://eprints.walisongo.ac.id/9527/

Kristiyanto, B. noor achsan. 2015. Pengembangan Model Pembelajaran Praktik Terpadu Siswa SMK Pariwisata (Disertasi, UNY). Retrieved from https://eprints.uny.ac.id/18552/

Karin, V, K. 2012. Responding To The Roots Of Terror, dalam Modul Metodologi Penelitian Terorisme, Program Magister Terorisme dalam Keamanan Internasional.103

Klaus Krippendorf, 2004. Content Analysis: An Introductions to its Methodology (second edition), California: Sage Publictions. 27

Mawardi, M., Wardani, N. S., Hardini, A. T. A., \& Kristin, F. 2019. Model Desain Pembelajaran Tematik Terpadu Kontekstual Untuk Meningkatkan Kebermaknaan Belajar Siswa SD. Scholaria: Jurnal Pendidikan dan Kebudayaan, 9 (1),48-61.

Tore Bjorgo (ed.), 2005. Root Causes of Terrorism: Myths, Reality, and Ways Forward. London and New York: Routledge.

Trianto,S.pd. 2007. Model Pembelajaran Terpadu Dalam Teori Dan Praktek. Jakarta: Presentasi Pustaka Publisher.

Wall, A. 2017. Curriculum Integration: An Overview. Georgia: Georgia Southern University 